\section{B A Institute of \\ YK Business Administration \\ 六下 \\ Karachi \\ Leadership and Ideas for Tomorrow}

\section{Business Review}

Volume 15 Issue 1

January-June 2020

$1-1-2020$

\title{
Optimization of non-monetary reward provisions: Evidence from the UK banking sector
}

\author{
Ese Okpebholo
}

Abdullah Zafar Sheikh

Institute of Business Administration, Karachi, Pakistan

Follow this and additional works at: https://ir.iba.edu.pk/businessreview

Part of the Finance Commons, Management Sciences and Quantitative Methods Commons, and the Marketing Commons

\section{(c) (1)}

This work is licensed under a Creative Commons Attribution 4.0 International License.

\section{Recommended Citation}

Okpebholo, E., \& Sheikh, A. Z. (2020). Optimization of non-monetary reward provisions: Evidence from the UK banking sector. Business Review, 15(1), 1-18. Retrieved from https://doi.org/10.54784/

1990-6587.1000

This article is brought to you by iRepository for open access under the Creative Commons Attribution 4.0 License and is available at https://ir.iba.edu.pk/businessreview/vol15/iss1/1. For more information, please contact irepository@iba.edu.pk. 


\title{
Optimization of non-monetary reward provisions: Evidence from the UK banking sector
}

\author{
Ese Okpebholo · Abdullah Zafar Sheikh
}

\begin{abstract}
This paper evaluates the current state of monetary and non-monetary rewards systems in place in the UK banking sector in an attempt to identify reasons for the preference of monetary rewards over non-monetary rewards. Data was collected from two banks, LLOYDS TSB and Royal Bank of Scotland. The selection of these two banks emanates from their recent bonus crises and the fact that they are both part nationalised, hence the need for a prudent reward system. Questionnaires were used to obtain data and the Evidence Based Reward Management (EBRM) methodology was used to highlight the effectiveness as well as the challenges being faced by the banks with regard to their current monetary reward provisions. Findings reveal that bank employees generally value monetary rewards more than they value non-monetary rewards. Nonetheless, some non-monetary provisions, which virtually do not cost much money, may form the basis for viable alternative reward provisions for bank employees. These findings can help in formulating a more egalitarian reward system in the banking sector.
\end{abstract}

Keywords Monetary rewards · Non-monetary rewards · Extrinsic and intrinsic rewards · Banking sector

\section{Introduction}

Rewarding employees is invariably one of the most vital provisions organisations use to win employees' satisfaction in the work place. Broadly, there are two types of reward systems: monetary and non-monetary. The extensive use of monetary rewards may be justified because they tend to be the major means for recruiting and retaining talent as well as providing tangible recognition of effort

Ese Okpebholo

London, United Kingdom

Abdullah Zafar Sheikh

Institute of Business Administration, University Road, Karachi-Pakistan

E-mail: azsheikh@iba.edu.pk

(C)Okpebholo E. and Sheikh, Z. A. 2020 
and contributions (Khan et al 2013; Igbaekemem 2014). Nonetheless, there is a need for organisations to look beyond just monetary reward provisions as the importance of non- monetary reward systems cannot be underestimated (Tausif 2012).

Lately, the UK banking sector has extensively relied on financial reward systems, especially the use of performance bonuses and share schemes, even in times of failed performances. This, therefore, questions the reliability of the use of monetary reward system in the sector. Furthermore, given a number of mainstream banks are subject to being rescued by taxpayers' money in the event of a failure, there is the need for a reward system that is 'fair' not just to the organisations but to the whole economy, and society in general. This study, therefore, attempts to evaluate the non-monetary reward systems being used by UK banks and their effectiveness on employee motivation. The study adopts a case study approach and collects data from two UK banks: the Royal Bank of Scotland Group (RBS) and Lloyds Banking Group (Lloyds TSB).

The UK banking sector has faced crises over the past decade. Despite the turbulence, the sector has continued to rely extensively on rewarding employees with huge monetary remunerations. Recent developments, such as those at RBS and Lloyds TSB where top executives have earmarked several hundred thousand pounds and sometimes millions in times, when losses were incurred and incompetent decisions made, have raised the possibility of a non-monetary reward system to complement the current system. In this backdrop, there may be a need for banks to depend less on financial rewards and more on non-monetary reward systems, especially for executive cadres.

The key issue with the monetary reward system, in most cases, is twofold. Firstly, a good number of large banks that have continuously used huge financial rewards in the form of bonuses have recently been in the position of losses, potentially implying that these bonuses in themselves were significant enough to cause losses. Secondly, a large number of these 'failed' banks are often rescued by taxpayers' money, as in the case of RBS and Lloyds TSB, implying that taxpayers in essence were indirectly paying for a failed reward system.

Although there is an apparent need for a robust financial system in a bid to recruit and retain talent, the current reward systems in banks have been greatly misused. This underscores the need to shift away from a reward system, which relies heavily on financial rewards towards a fairer and possibly non-monetary reward system for the long-term sustainability of the banks, shareholders and taxpayers. In this context, it is important to understand the reasons why existing practices, of heavy reliance on the monetary system, prevail. This, therefore, calls for a vigorous inquiry as to why UK banks excessively rely on monetary reward provisions as opposed to the non-monetary reward systems? This research question also entails identifying the potential challenges faced by banks in adopting the non-monetary reward provisions. 


\section{Theoretical underpinning}

\subsection{Reward systems}

Employees are the spine of any organisation and the quality of the workforce in an organisation can go a long way in giving an organisation a sustained competitive advantage. Rewarding employees serves as an essential means of achieving this sustained competitive advantage (Kerr and Slocum Jr 2005). Traditional reward systems typically involve the payment of a base pay to employees that is determined by the job specification, the need to pay a going competitive rate in the job market and the need to maintain equity among employees (Kerrin and Oliver 2002). However, reward systems have moved from these traditional methods, over the years, to other dynamics such as team based performance and non-financial rewards (Agarwal and Singh 1998; Silverman 2004; Igbaekemem 2014).

Lawler and Jenkins (1992) states that a firm's strategy is just as important as the reward systems in place, as a mismatch could lead to derailed goals. Boyd and Salamin (2001) for instance suggest that firms should merge their compensation systems into their corporate strategy. This body of literature has developed to what is often called Strategic Reward Systems (Lawler and Jenkins 1992; Boyd and Salamin 2001). According to Lawler and Jenkins (1992), once a strategy is developed by an organisation, the organisation needs to focus on the kind of culture, behaviour and human resources that would make it most effective. Boyd and Salamin (2001) suggested that reward systems are central to an organisation's overall strategy and found that managerial discretion played a vital role in the nature of reward systems adopted in an organisation.

\subsection{Monetary and non-monetary reward systems}

Early motivation scholars such as Marslow (1954) and Herzberg (1966) generally agreed on two key types of motivational forces that influence individuals. These are identified as intrinsic and extrinsic forces. According to Silverman (2004) intrinsic motivation are internal thoughts and feelings that feed one's desire to achieve, perform and become involved in activities. Aworemi et al (2011) suggest that intrinsic rewards are positive emotional experiences resulting directly and naturally from the individual's behaviour or results. Deci et al (2001) define intrinsic rewards as being obtained when individuals do tasks for their own sake without any apparent reward being expected. These may include the enjoyment of learning a new task, a feeling of accomplishment from performing a job well done and a sense of flow or engagement when work is performed smoothly. Aworemi et al (2011) state that extrinsic rewards are anything received from another person that the recipient values and is contingent on his or her behaviour or results. Extrinsic rewards may include pay checks, performance bonuses and other forms of financial rewards.

Furthermore, apart from distinguishing rewards between extrinsic and intrinsic categories, rewards are also often classified as being monetary and nonmonetary. One general conclusion that is often drawn is that monetary rewards 
are inherently extrinsic in nature. Monetary rewards are seen to have a 'payment' or 'cash' attribute while non-monetary rewards are given as 'recognition' for a high level of accomplishment or performance (Silverman 2004).

It is important to note that there are important distinctions between financial and non-financial rewards. Hansen et al (2002) explains that the financial rewards have an 'in order to' attribute that helps serve as an incentive; thus an employee does something in order to obtain the reward. Silverman (2004) identifies that financial rewards are often spelt out and promised from the outset, while non-monetary rewards have some form of post hoc approach to them. It is important to note that non-financial may have a financial value in some cases. However, it should just not have a cash attribute (Silverman 2004). Nonmonetary rewards on the other hand can be either intrinsic or extrinsic depending on the particular non-monetary reward.

It is generally believed that extrinsic rewards, which are predominnatly financial rewards, undermine intrinsic motivation. Hence, there has been some insight into alternative means of motivating individuals especially in the workplace (Abdullah and Wan 2013; Fang et al 2013; Shaw and Gupta 2015; Tausif 2012). Intrinsic motivation is an important driver of employee attitudes and behavior (Cho and Perry 2012). According to Silverman (2004) financial rewards stimulate extrinsic motivation, and do not have much impact on intrinsic motivation whereas non-financial rewards such as recognition, impact intrinsic motivation. Pfeffer (1998) identifies that most organisations place too much emphasis on financial motivation while ignoring and neglecting other aspects of motivation. The resultant effect is that financial rewards increase the extrinsic motivation to join and continue with an organisation but undermine the intrinsic motivation needed for the job.

\subsection{Monetary and non-monetary reward systems in the UK banking sector}

The UK banking sector is one of the oldest financial sectors in the world with London very often referred to as the financial capital of the world. Reward systems in the UK banking sector have been shaped mostly by the need to pay back with performance. Traditional reward systems that operated in the UK banking system in the 1970s and 1980s placed more emphasis on seniority based incremental pay and grade systems, where workers were mostly rewarded for the length of service (Storey et al 1997).

However, the notion of a 'lifetime career' disappeared in the sector with increasing competition and job insecurity WI-bite et al (1998) and because of the nature of competition in the UK banking sector, reward strategies have had to move from the traditional incremental and grade system towards some form of contingent pay (Storey et al 1997). Storey et al (1997) noted that a complete shift to performance related pay was made in 1998 by the biggest of the big four banks at that time, the NatWest Bank.

Up until the recent financial crises in the banking sector, rewarding employees by financial rewards for performance seemed a viable idea. Different forms of financial compensations were introduced over the years ranging from 
increased base pay to bonuses to profit sharing and then share option schemes. Van der Stede (2009) highlights that virtually all banks reward systems were based on short-term performance whereas these performances were not essentially sustainable in the long run and indeed detrimental to the banks' future. The eventual consequence of this, in some cases, was that bonuses were being paid to the employees by the time the ailing performances of the banks had become apparent. Consequently, the reward system in British banks potentially made many employees myopic and hungry for short-term performance at the expense of long-term value creation (Van der Stede 2009).

Papasolomou-Doukakis (2002b) states that the UK retail banking reward system is more tied to the organisational goal of high sales volume hence, customer contact personnel had more opportunities and actually received more of the lucrative financial monetary rewards than non-customer contact personnel. She claimed that these extrinsic financial rewards would have been more appealing to employees than intrinsic non-monetary rewards, which were most often tied to service quality targets. She feared that this kind of reward system would lead employees to concentrate their efforts on achieving sales target at the cost of quality of service. The consequence of this to the UK retail banking sector would be a decline in the quality of customer service.

Executive reward systems differ from the broad reward systems, used by banks, in many ways and are predominantly monetary in nature. These executive reward systems have come under scrutiny in recent years not only in the UK but throughout the world. In the UK, the bonus culture in the financial system had gained the attention of the House of Common's Treasury Committee and in May 2009, they released the report on 'Banking Crisis: Reforming Corporate Governance and Pay in the City'. The report states that the reward systems existing in banks encouraged reckless and excessive risk taking and was detrimental to shareholders and the long-term sustainability of the banks. They made certain recommendations to the Financial Services Authority (FSA). They also emphasised viability of the reward systems to banks and suggested that banks should ensure shareholders are taken on board in making such decisions.

The most common procedure of determining executive reward system in UK banks is through the discretion of the board of directors in the form of compensation consultants. Various studies have sought to establish the effectiveness of reward systems adopted through the use of compensation consultants. Goh and Gupta (2010) using a sample of FTSE 350 firms in the UK find that firms which use compensation consultants generally offer higher financial rewards to their executives. Studies such as Kabir and Minhat (2010) using 175 UK companies (including all top five UK banks by capital base) also support these findings. One conclusion that can be drawn from these findings is that large companies including the big banks indulge in the use of compensation consultants to provide legitimacy and justification for the payment of high compensation to executives and these findings provide useful insights to the huge bonuses being paid in banks.

On the disadvantages of using financial rewards in the UK banking sector, Chen et al (2011), found that the lavish financial reward system of the largest five failed British banks does not empirically reflect the companies' performance

Business Review: (2020) 15(1):1-18 
and provides little reward for shareholders. They conclude that an ineffective reward system could potentially contribute to bank failures. The fact that shareholders often are not satisfied with excessive financial reward systems in UK, banks today can be justified by statements made by Peacock (2009). In her article in Personnel Today, Peacock (2009) stated that the UK Shareholders' Association (UKSA) urged the UK financial Investments who owned $43 \%$ stake in Lloyds TSB to block the bank's bonus and reward policy in 2009.

These findings seem to suggest that the British banks place heavy emphasis on extrinsic financial reward provisions at the expense of non-financial rewards. However, Malhotra et al (2007) found that the roles and job levels of employees in UK banks are the determinants of the type of reward that employees value the most. Their findings suggest that lower level employees value certain intrinsic non-financial rewards. They found that participation in decision-making, autonomy and role clarity go a long way in motivating employees, such as customer service personnel and call centre operators. According to them, opportunity to participate in decision making gives employees some sort of emotional attachment to the organisation and makes them feel like a part of it. They claimed role clarity helps to enhance employee empathy towards customers and this helps them align better with the objectives and goals of the organisation. Their findings also suggest that 'satisfaction with benefits' was the only extrinsic reward that motivated lower level employees, dealt with.

Using five banks as their empirical setting (Barclays, Lloyds TSB, Cooperative, NatWest and Royal Bank of Scotland) Papasolomou-Doukakis (2002a) found that banks primarily link achievement of service quality with some intrinsic non-monetary rewards. They found that intrinsic, non-monetary rewards that were often used were service awards, presentation ceremonies and public praises. Non-monetary awards that were of importance included gifts, medals, plaques and travel coupons. Kelemen and Papasolomou (2007) found that reward systems in place in banks within the UK reflect a high correlation with customer service targets. They reinforce the findings of Papasolomou-Doukakis (2002b) that banks primarily link the achievement of service quality with intrinsic and non-monetary rewards. Her findings also revealed that using monetary reward systems in banks divide people by creating massive status differences. She explains that this is detrimental to the whole reward system since banks these days try to use a reward system that is targeted at all levels of staff and build a 'One Bank' spirit while fostering team work as well. She further expresses that non-reward systems are, sometimes, administered at head office level but could prove very effective if they are administered at branch level (Papasolomou-Doukakis 2002a).

Reviewing case studies of a number of firms in the UK, Armstrong and Stephens (2005) emphasised that the era in which Lloyds TSB Bank (which is one of the case study banks in this study) relied solely on financial rewards has passed. They identified that the bank is increasing emphasis on creating a 'compelling employment offer', which is not as easily replicable as simply rewarding staff through financial rewards.

To encapsulate the above, reward systems in UK banks at board level and senior management level are different from the reward systems of middle man- 
agement and junior staff. It can be inferred from the above discussions that UK banks generally separate their executive reward system from the general reward system adopted by the bank as a whole. The effect of this is that board level reward strategies include the extensive use of financial rewards, which they claim is the best way to attract and retain high quality top-level staff while general reward strategy is not as generous financially and tries to incorporate non-monetary reward systems. This underlines the importance of moving away from a predominantly extrinsic reward system towards a more, intrinsic, nonmonetary reward system, for the long-term sustainability of the banks, shareholders and taxpayers.

This study therefore explores the reasons for the dependence on monetary reward systems over non-monetary reward systems by the two selected banks, the RBS group and Lloyds banking group and identifies the potential challenges faced by banks in adopting non-monetary reward provisions.

\section{Methodology}

The scope of the study is limited to two banks that have recently had their reward systems questioned in the wake of declining performances. The two banks are Royal Bank of Scotland and Lloyds TSB. Data was collected from employees of these banks in branches situated in the City of London. A total of 180 questionnaires were administered across six branches of Lloyds TSB and RBS in London, with an average of 30 questionnaires distributed in each branch.

For Lloyds TSB, the branches included the Stratford branch, the Highbury and Islington branch and the Barking branch. For RBS, the branches included the Liverpool Street, Canary Wharf and Holborn Circus branches. A total of 126 questionnaires were returned, signaling a $70 \%$ response rate. The questionnaires were semi structured allowing for both close and open-ended questions. The questionnaire was modelled to obtain data useful in analysing reward systems through the Evidence Based Reward Management (EBRM) methodology.

\subsection{The Evidence Based Reward Management Methodology}

The Evidence Based Reward Management Methodology (EBRM) was developed by Armstrong and Stephens (2005) of the Institute of Employment Studies in the UK and has become an effective tool, often used by large organisations, in evaluating the effectiveness of their reward system. Proponents of the methodology argue that effective reward systems have to be evidence based.

This methodology examines the flaws of traditional reward systems and tries to improve these flaws to better manage these systems. The most important challenge of traditional reward system evaluation which EBRM conquers is the lack of measurement techniques for the rewards. Hence by identifying the quality and not just quantity of rewards through basic good practice principles, EBRM becomes an effective tool in analysing non-financial reward systems in an organisation. The EBRM identifies the 10 most important criteria of an effective reward management system used by an organisation. The diagram below

Business Review: (2020) 15(1):1-18 
illustrates the basic framework for EBRM.

The study used the EBRM methodology to help answer the research ques-

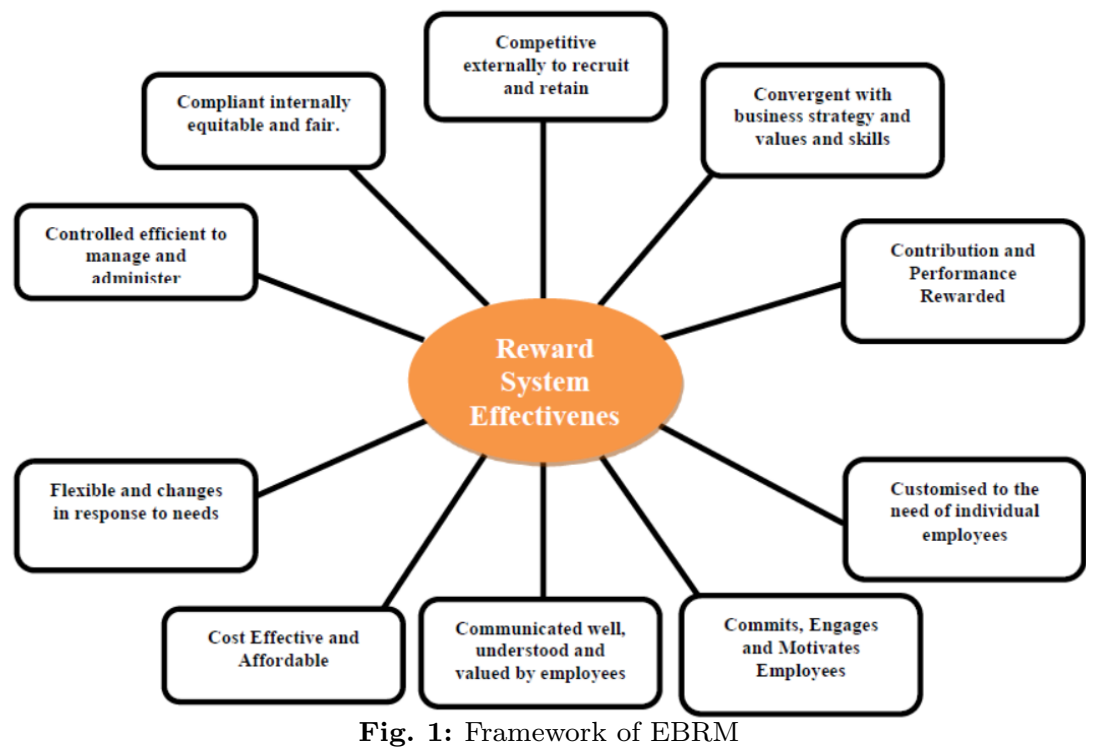

tions. Once the data, on the existing monetary and non-monetary rewards used by the banks, has been obtained, the framework in the above diagram provides a guide as to what kind of information is necessary in evaluating the effectiveness of each type of existing reward system in the bank as a whole. The framework is particularly useful in analysing the effectiveness of the non-monetary reward system used by banks.

\subsection{Operational definitions of the study variables}

Monetary rewards: These are direct financial components of a reward system, which generally seem to have a 'payment' or 'cash' attribute, such as salary, bonuses and commissions.

Non-monetary rewards: These are non-financial components of a reward system such as recognition for work well done, job enrichment and flextime work options.

Intrinsic reward: An intrinsic reward is an intangible form of award such as recognition, a sense of achievement, or a conscious satisfaction.

Extrinsic reward: An extrinsic reward is an award that is tangible and given to employees for accomplishing something. It is a tangible recognition of one's endeavor. Motivation based on tangible rewards, is external to the individual and is typically offered by a supervisor or manager. 


\subsection{Brief overview of the case study banks}

The two banks selected as cases for this study are the Lloyds TSB Banking Group and the Royal Bank of Scotland Banking Group. As stated previously, the justification for the selection of these banks emanates from the fact that both of these banks have recently encountered financial crises. This crisis is partly prompted by excessive bonus systems which is a reflection of their reward system as well as the fact that they are now both part owned by the government, hence they are indirectly accountable to taxpayers.

The Lloyds Banking Group dates as far back as 1765 and was originally set up by John Taylor and Sampson Lloyds as a private business in Birmingham, England. Over the years what is known as Lloyds TSB today has undergone a series of mergers and acquisitions. In the thick of the global financial crises in 1998, Lloyds bank took over Halifax Bank of Scotland (HBOS) in a move that raised public outcry especially in terms of lessening the gains from competition as the two banks were major players in the market, particularly in Scotland. The merger was to reveal more cracks in the banking industry as both banks in themselves had internal problems and lacked the synergies that were anticipated. The eventual result was the inclusion of the bank in the 37 billion bailout plan by the government. Due to the bail out by public funds, public opinion was against the payment of huge bonuses to executives of the bank. In February 2012, the bank announced a major change in the bonus reward systems of its executives and stated that it would claw back as much as 1.5 million pounds in bonuses to executives as well as a continual reduction in its bonus pools in subsequent years (Treanor 2012).

The Royal Bank of Scotland was formed in 1727. It also underwent a series of mergers and acquisitions over the centuries and by 1970 all its constituent trading arms joined together to form Williams and Glyn's Bank. The bank went back to trading as Royal Bank of Scotland in 1985 and in 1988 it acquired Citizen's Financial Group to give it a huge presence in the US. In 2000 the bank acquired NatWest bank in a move which formed the third biggest banking group in the UK. The acquisition initially proved to be a success but was halted by the financial crises that hit the banking sector. RBS was so badly hit by the financial crises that the government took part ownership of the bank in 2008 and as much as $82 \%$ of its shares were then owned by the government. Recent criticisms of the RBS bonus scheme that has seen Chief Executive Stephen Hester poised to receive a bonus as much as 1 million pounds in one year have made the bank review its bonus culture.

The reward system in these two banks is of special public interest because they are part nationalised banks with the government owning a considerable proportion of shareholding. The Treasury Committee Report (2009), mentioned earlier, particularly evaluates the reward systems in these two banks. This report identified that the basic salary for board level and senior management executives, in these banks, was roughly from 1 million to 1.25 million pounds per year. These executives, on average, have the opportunity to earn two to four times that amount in the form of other financial rewards as well as having the right to own shares about two to five times their salary depending on their 3 year 
performance. It also found that below board level employees, especially within investment banking, such as an equity trader with about eight years trading experience would earn an average basic pay of about 90,000 pounds annually but could go on to earn as much as 500,000 pounds in financial rewards for performance. These figures indeed point to the fact that these banks rely extensively on financial rewards in compensating workers for exceptional performance.

\section{Findings}

The study used random sampling of respondents. Hence, it is expected that respondents selected to make the sample to be analysed are not biased but reflect the true nature of the population. The gender distribution of the respondents comprises $62 \%$ of the sample being male and $38 \%$ being female. The highest proportion of workers in the banks were those in the age range 20-29, with almost 45 respondents in that age range. This was closely followed, in decreasing order, by the 30-39 and 40-49 age ranges. The least proportion of age range was those above 60 with no respondents at all and just about 6 respondents were in the 50-59 age range.

Identifying the level of education, and possession of a professional qualification, of the respondents is key information that would be useful eventually in analysing reward systems. The study found that university graduates were the largest group with about 51 respondents having at least one university degree. The number of respondents without university education was considerably high at $36 \%$. Of all the respondents, however, $64 \%$ possessed some form of professional qualification. The years of banking experience may also go a long way in influencing how individuals perceive the reward system. The highest number of respondents had between 1-5 years of banking experience followed by individuals that had between 11-15 years of experience. Workers that had over 21 years had the lowest frequency followed by workers that had 6-10 years.

\subsection{Evidence Based Reward Management (EBRM)}

The Evidence Based Reward Management (EBRM) methodology is used in the study to evaluate the current reward systems that exist in the banks in a bid to identify lapses and challenges that may be inherent in the reward system. The methodology uses 10 points to assess the effectiveness of the reward system and these points are evaluated in the sections below. Figures 2, 3 and 4 serve as a guide to present the findings of the EBRM analysis, followed by a detailed analysis of these depictions.

Figures 2, 3 and 4 above show the extent to which employees agree to each of the 10 requirements of the EBRM methodology, used in evaluating the effectiveness of the reward systems in the two case study banks. Figure 4 shows the percentage of employees that disagree with the statement that each requirement of the EBRM is functional in their bank. The point by point detailed findings are discussed below:

Point 1: The reward system is competitive enough to retain employees at 


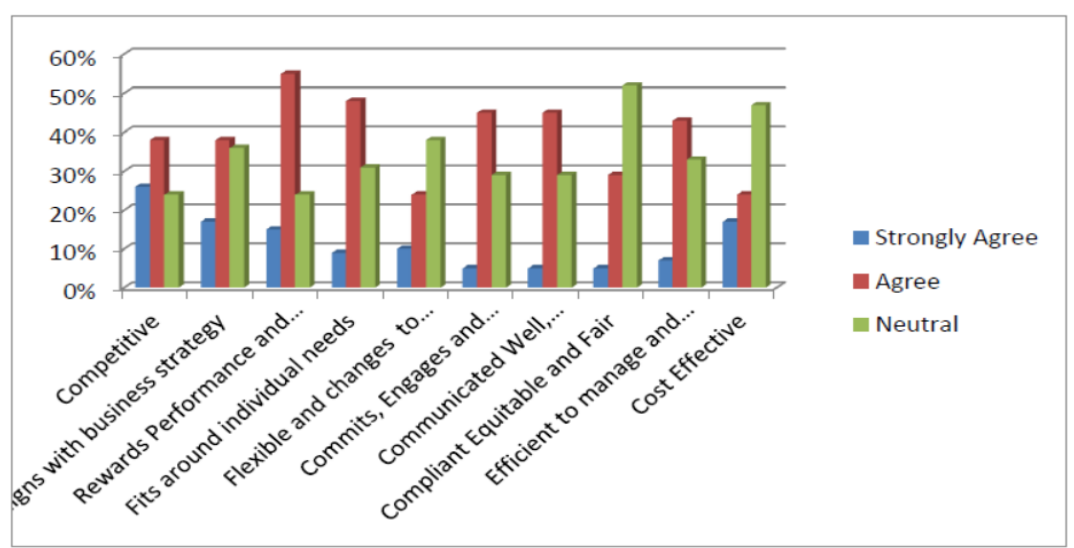

Fig. 2: Findings of the EBRM analysis

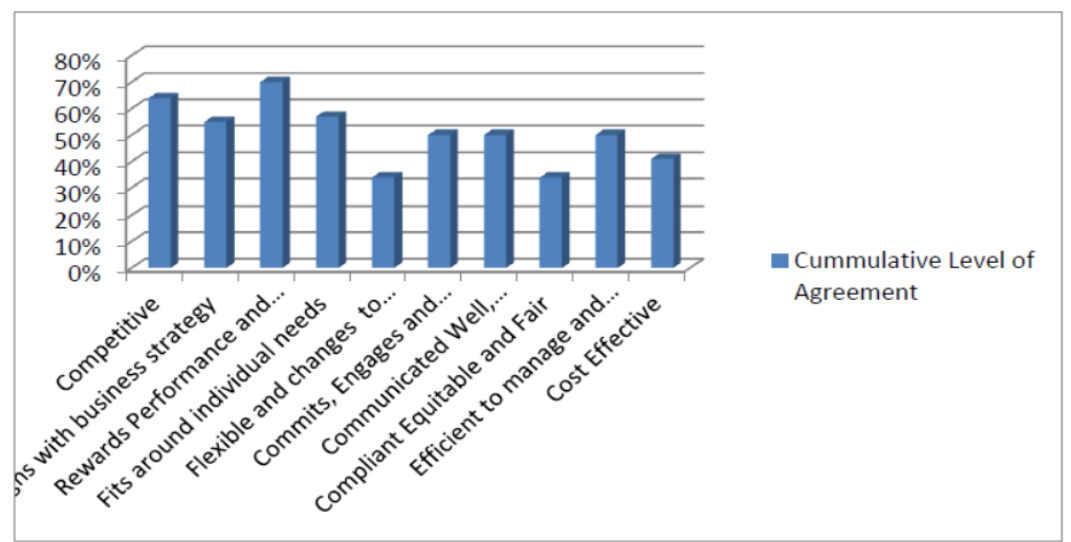

Fig. 3: Cumulative level of agreement

the bank: About $64 \%$ of respondents agreed that the reward system existing in their banks was competitive enough to retain them. A further $26 \%$ strongly agreed with this requirement, which was the highest level of strong agreement across all 10 requirements. This may suggest that the industry standards of reward system in banks are currently very competitive and thus potentially the reason why banks go extra lengths in retaining staff, especially through the use of extensive monetary rewards. Only about $12 \%$ of respondents disagreed with this requirement in total.

Point 2: The reward system should align with the business strategy of the organisation: This was highlighted to be true according to the financial statements of the banks. These types of reward systems are called Strategic Reward Systems and have been evaluated extensively in the works of Lawler and Jenkins (1992) and Boyd and Salamin (2001). Findings revealed that more than half of the employees believe the reward systems used in their banks were strategic in nature. A negligible $9 \%$ of respondents, however, disagreed with this statement.

Point 3: The reward system rewards performance and contribution: This

Business Review: (2020) 15(1):1-18 


\section{E. Okpebholo, A. Sheikh}

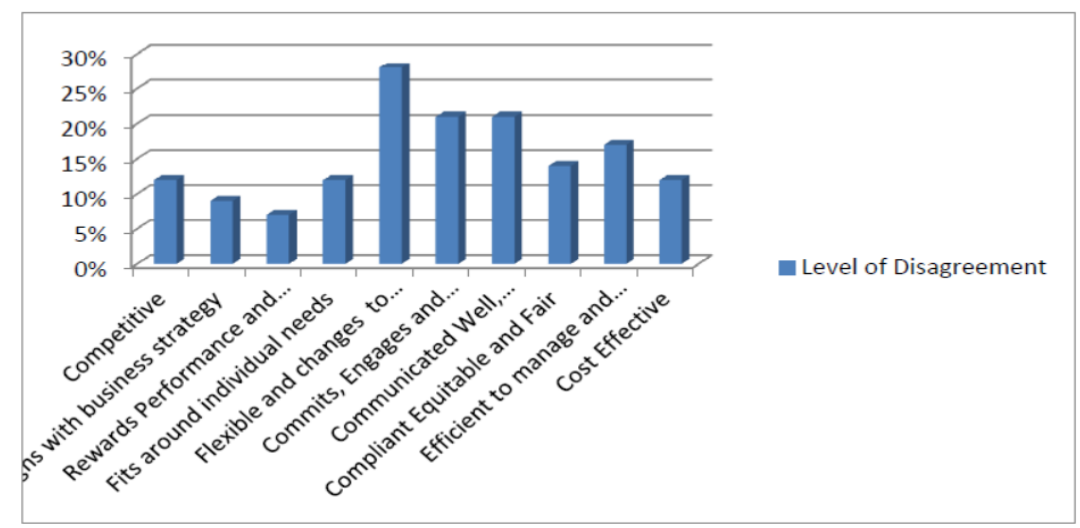

Fig. 4: Level of disagreement

requirement is classified as arguably the most important requirement of a reward system since reward systems are generally in place to reward performance and contribution (Kerr and Slocum Jr 2005; Deci et al 2001). Interestingly, this requirement gained the highest level of agreement among employees in this research as well. An overwhelming $70 \%$ of respondents agreed that the reward system used in banks reward performance and $55 \%$ of these employees strongly believed this to be true. To affirm this to be extremely valid, this requirement also gained the lowest level of disagreement amongst employees with just $7 \%$ of employees. This finding suggests that there appears to be quite a high level of efficiency in the reward system used by these banks.

Point 4: The reward system fits around the individual worker's needs: It was observed that $57 \%$ of workers felt that the reward system fits around their individual needs. This requirement suggests a personal level of approval for the reward system. About $12 \%$ of workers, however, disagreed with this.

Point 5: The reward system is flexible and changes in response to individual needs: It was noted that most workers were neutral about this since the neutral employees were the mode with about $38 \%$. It was also a joint lowest score in terms of workers agreeing with it as just $32 \%$ of workers felt this was true and this suggests a lapse in this regard. Furthermore, almost 30\% of workers disagree that this is the case. Hence, it can be said that many bank workers feel the reward system operating in their banks is not flexible enough and does not change in response to the needs of the workers.

Point 6: The reward system commits, engages and motivates workers: About $44 \%$ of workers agreed that the reward system in place commits, engages and most importantly motivates them. A further $4 \%$ strongly agreed to this but still just about $48 \%$ of workers agreed to this. This suggests that the reward system can be improved in this regard to increase commitment, engagement and motivation of workers.

Point 7: The reward system used is well communicated, understood and valued: The findings on this requirement of effective reward management were observed to be very similar to those in the section above, with $48 \%$ of workers totally agreeing that the reward system is communicated well, understood and 
valued. This suggests that an improvement is needed in this regard as well.

Point 8: The reward system used is compliant, equitable and fair to all employees: It was observed that about $52 \%$ of workers were neutral regarding the fact that reward systems currently used were complaint, equitable and fair. This clearly suggests that the majority of respondents did not believe that the system is complaint, equitable and fair. Combining the percentage of those that were neutral to those that disagreed, it implies that $66 \%$ of all workers do not agree to this requirement. Hence, compliance, equity and fairness of reward systems in banks ostensibly needs to be improved.

Point 9: The reward system is efficient to manage and administer: Although this requirement is one of those that is likely to obtain the best responses from managers, the study still tried to seek the general opinion of employees on this account. It was found that slightly below $50 \%$ of the workers believed the reward system is efficient to manage and administer. However, about $16 \%$ of employees believed this to be untrue. If these findings are assumed to be true, the suggestion here is that banks should improve the management and administration of rewards, especially at the branch level.

Point 10: The current reward system is cost effective: This requirement also required a response from managers to have a more clear insight. As expected, the mode of the findings was that most employees were neutral about this requirement, with $46 \%$ of them being neutral. However, in the opinion of $40 \%$ of the selected respondents, the current reward system was actually cost effective. Only about $14 \%$ disagreed with this point. Again, assuming that these findings are correct, the banks can improve the cost effectiveness of their reward systems.

\section{Discussion}

The key aim of the study was to explore the reasons why the two case study banks tend to depend more on monetary rewards at the expense of non-monetary rewards. It was noted that the banks generally used monetary rewards in the form of remuneration and allowances, which are basic and necessary to retain key staff in employment. However, the study was more interested in the extra monetary and non-monetary rewards that banks used to reward extra performance by employees. Findings suggest that the dominant monetary reward used to reward performance were cash bonuses to employees. It is, however, important to note that profit sharing or gain sharing are other common monetary reward items but were not found to be present in these banks.

The types of non-monetary rewards were medical and life insurances, dental plan, additional pension, holiday trading, educational vouchers, child-care vouchers, matched learning/training, verbal praise, written praises and job enrichment. It was further noted that over two-thirds of bank workers valued monetary rewards above non-monetary rewards. This may be explained by the findings that a good number of employees believed that monetary reward provisions are most effective ways of rewarding employees (Igbaekemem 2014). About $60 \%$ employees believed that monetary rewards were the most effective way of rewarding employees in banks, more or less in line with the notion that extrin- 
sic reward provisions influence workplace motivation (Gerhart and Fang 2015). Another interesting observation was that bank workers valued non-monetary rewards that were liquid in nature, such as shares, just about as much as pure monetary rewards.

To establish whether employees would welcome an effective non-monetary system if such a provision was introduced, the study tried to seek the opinion of employees. Opinions were divided as to whether or not banks should try and use more non-monetary rewards than they currently use. A vast majority of respondents, however, believed that the banks should not consider using more non-monetary rewards than monetary rewards at any point in time. This again substantiates that a good number of bank employees do not value non-monetary rewards for performance as much they value monetary rewards.

Another objective of the study was to explore possible non-monetary rewards that banks could potentially use to improve their current non-monetary reward system. In achieving this, the study proposed certain non-monetary rewards that were believed to be motivating employees in a bid to evaluate which ones employees valued the most (Shahzadi et al 2014). The non-monetary rewards suggested were verbal praise from management, written praise from management, public appreciation and recognition, awards, gifts and vouchers, job enrichment and training.

Job enrichment was clearly the most valued non-monetary reward with an overwhelming $87 \%$ of employees recommending it. This was found to be consistent with the findings of Malhotra et al (2007) who found that UK bank employees especially those with customer facing responsibilities were most highly motivated when they were presented with job enrichment opportunities. This is broadly in line with existing studies, which generally suggest non-monetary rewards to be strong determinants of job satisfaction at the workplace (Abdullah and Wan 2013; Tausif 2012).

As stated above, it has been established that the current reward system used by banks depends more on monetary reward system and that employees are quite satisfied with this nature of reward because they place a higher value on them. Nonetheless, there are certainly going to be challenges and shortcomings of the current over-dependence on the monetary reward system that may give some justification towards a tilt to non-monetary rewards.

In identifying the challenges to the reward system, the study tried to use the EBRM methodology. The methodology uses 10 aspects of reward management that are considered to be an embodiment of an effective reward system. A negative response in any of these 10 aspects suggests a shortcoming in that aspect. The EBRM analysis highlighted the competitive nature of rewards in banks as most employees agreed that what they obtained in rewards in their individual banks was enough to retain them at the bank. This suggested that the banking industry was in itself competitive in terms of rewards and hence would require banks to be competitive in order to retain staff. This may also give an insight into the reasons for extensive use of monetary rewards, which is the fear of losing staff in a competitive reward environment.

The EBRM analysis also identified the existence of a Strategic Reward System by banks, which means rewards must be consistently aligned with the busi- 
ness strategies of the banks. This might pose a challenge as rewards then need to be continuously evaluated and measured, at regular intervals, to ensure they are in line with overall business strategy.

A vast majority of employees agreed that rewards systems operating in their banks reward performance and contribution, thus implying the effectiveness of the current rewards system. However, the EBRM analysis identified two major shortcomings of the current reward system. The first is that it is not flexible and does not cater to individual needs. About 30\% of workers disagreed to this and a further $40 \%$ were neutral about it. This clearly suggests that the reward system was ineffective when it comes to satisfying individual needs of the workers. The second major shortcoming of the reward system being used was that it was not as compliant, equitable and fair as employees would have wanted it. A massive $52 \%$ of respondents suggested this to be true as they remained neutral to the opinion that the reward system was compliant, equitable and fair. Adding this figure to the $14 \%$ of people that disagreed, it implies about $66 \%$ of the bank employees do not think the system is complaint equitable and fair. This is evident in reality through enormous bonus payments to senior management officials. Another important viewpoint from the respondents suggested that the reward system could be improved by ensuring that rewards and perks are properly communicated, understood and valued; that the reward system is efficient to manage and administer and that the reward system ought to be cost effective.

\section{Managerial implications}

A number of managerial implications can be drawn from this study with regard to the utility of non-monetary rewards in the banking sector. Given the exorbitant cost associated with some of the monetary rewards on offer in the banking sector, tested and proven provision of effective non-monetary rewards may prove to be a welcome respite in crunched times.

This study revealed that some of the non-monetary provisions, which virtually do not cost much money, may prove to be considerably valuable for bank employees such as publicly recognizing good work, flexible work hours and job enrichment among others. It is, therefore, crucial for organizations to draw managers' attention to the importance of these, intrinsic, non-monetary reward provisions. The use of non-monetary reward options can also help banks foster a more egalitarian environment by bringing some equity to the nature of rewards, especially rewards such as flexible work hours and job enrichment. This becomes all the more important in banks, which are usually characterized with higher wage differentials between and upper and lower strata of employees.

\section{Research limitations and areas for future research}

The most basic limitation of the study is the issue surrounding the representativeness of the whole UK banking industry since the two case banks selected for this study do not represent the entire UK banking sector. As much as this 
may reflect some important issues of reward systems in the banking sector, it may not provide a true account of the entire sector. For instance, one limitation linked to this is that the case study banks used only cash bonuses and salaries as monetary rewards but in reality other banks may also use be using rewards like profit sharing etc. Future researchers should use a larger sample, comprising of a cross section of banks, from different tiers of the British banking sector.

Another limitation stems from the potential unwillingness of respondents to give a true account of their actual reward needs, primarily out of fear of being singled out, although the questionnaires were administered in an anonymous manner. Finally, Armstrong and Stephens (2005) argued that the EBRM measures reward effectiveness not in quantitative terms but in qualitative terms and they suggest 6 aspects of effective reward measurement criteria that should be used. However, these measures are in themselves subjective since they are not in absolute terms and various organizations measure success according to their priorities. Hence, as effective as the EBRM claims to be, its qualitative rather than quantitative approach may still be questioned.

A further limitation in the use of the EBRM methodology is that certain aspects are best answered by managers who handle rewards. Aspects such as cost effectiveness and efficiency of the reward systems can be most profoundly explained by the management. Future, more astute organizational researchers can seek to explore issues surrounding cost-effectiveness of reward systems by investigating a cross-section of respondents, including management representatives. For instance, further research may seek to identify the optimal level of both monetary and non-monetary rewards a firm should employ to motivate employees.

\section{Conclusion}

This study attempted to critically evaluate the reward systems in place in the two case study banks in the United Kingdom (RBS and Lloyds TSB). The study furthered our understanding about the underlying practices and employee perceptions regarding the existing reward systems in the two case study banks. The effectiveness of the reward systems was assessed using the EBRM methodology and a number of lapses and challenges were identified in the reward systems used by these banks. Although, it was found that most employees valued monetary rewards more than non-monetary rewards, the study identified some shortcomings in the extensive use of monetary rewards. The current reward systems were also found not to be sufficiently flexible to suit individual employee needs.

Non-monetary rewards can potentially bring some flexibility and may, therefore, respond to individual needs in a more effective manner. For instance, an employee may prefer to forgo a double pay weekend shift for quality weekend time with their families. The other major shortcoming of the system was that it lacked equity and was exorbitant especially in the case of higher-level staff. Non-monetary rewards may possibly bring some equity to the nature of the reward system. Furthermore, it was identified that workers value monetary rewards more but value non-monetary rewards that have a monetary value quite 
as much as they value monetary rewards. Banks may, therefore, consider introducing more non-financial rewards of this nature as they would be clearly appreciated. Examples may include share options, shopping vouchers, and paid holidays, to mention a few.

In conclusion, an optimal reward system must have a combination of monetary and non-monetary provisions at a level that ensures that employees are motivated to perform well. A suggestion of this optimal combination is the one which satisfies the ten requirements of an effective reward system, as proposed by the EBRM methodology.

\section{References}

Abdullah AA, Wan HL (2013) Relationships of non-monetary incentives, job satisfaction and employee job performance. International Review of Management and Business Research 2(4):1085

Agarwal N, Singh P (1998) Organisational rewards for a changing workplace: an examination of theory and practice. International Journal of Technology Management 16(1-3):225-238

Armstrong M, Stephens T (2005) A handbook of employee reward management and practice. Kogan Page Publishers

Aworemi JR, Abdul-Azeez IA, Durowoju ST, et al (2011) An empirical study of the motivational factors of employees in nigeria. International journal of economics and finance $3(5): 227-233$

Boyd BK, Salamin A (2001) Strategic reward systems: A contingency model of pay system design. Strategic management journal 22(8):777-792

Chen JJ, Zhang H, Xiao X, Li W (2011) Financial crisis and executive remuneration in banking industry-an analysis of five british banks. Applied Financial Economics 21(23):1779-1791

Cho YJ, Perry JL (2012) Intrinsic motivation and employee attitudes: Role of managerial trustworthiness, goal directedness, and extrinsic reward expectancy. Review of Public Personnel Administration 32(4):382-406

Deci EL, Koestner R, Ryan RM (2001) Extrinsic rewards and intrinsic motivation in education: Reconsidered once again. Review of educational research 71(1):1-27

Fang M, Gerhart B, Ledford Jr GE (2013) Negative effects of extrinsic rewards on intrinsic motivation: More smoke than fire. World at Work Quarterly 16(2):17-29

Gerhart B, Fang M (2015) Pay, intrinsic motivation, extrinsic motivation, performance, and creativity in the workplace: Revisiting long-held beliefs. Annu Rev Organ Psychol Organ Behav 2(1):489-521

Goh L, Gupta A (2010) Executive compensation, compensation consultants, and shopping for opinion: Evidence from the united kingdom. Journal of Accounting, Auditing \& Finance 25(4):607-643

Hansen F, Smith M, Hansen RB (2002) Rewards and recognition in employee motivation. Compensation \& Benefits Review 34(5):64-72

Herzberg F (1966) Work and the nature of man

Igbaekemem G (2014) Monetary incentives motivates employees on organizational performanace. Global Journal of Arts Humanities and Social Sciences UK, European Centre for Research Training and Development Press

Kabir R, Minhat M (2010) Multiple compensation consultants and ceo pay. In: annual meeting of European Accounting Association, Istanbul, Turkey

Kelemen M, Papasolomou I (2007) Internal marketing: a qualitative study of culture change in the uk banking sector. Journal of Marketing Management 23(7-8):746-768

Kerr J, Slocum Jr JW (2005) Managing corporate culture through reward systems. Academy of Management Perspectives 19(4):130-138

Kerrin M, Oliver N (2002) Collective and individual improvement activities: the role of reward systems. Personnel review

Khan I, Shahid M, Nawab S, Wali SS (2013) Influence of intrinsic and extrinsic rewards on employee performance: The banking sector of pakistan. Academic Research International 4(1):282

Business Review: (2020) 15(1):1-18 
Lawler E, Jenkins GD (1992) Strategic reward systems. Handbook of industrial and organizational psychology 3

Malhotra N, Budhwar P, Prowse P (2007) Linking rewards to commitment: an empirical investigation of four uk call centres. The International Journal of Human Resource Management 18(12):2095-2128

Marslow A (1954) Motivation and personality

Papasolomou-Doukakis I (2002a) Internal marketing: a means for creating a sales or marketing orientation? the case of uk retail banks. Journal of Marketing Communications 8(2):87100

Papasolomou-Doukakis I (2002b) The role of employee development in customer relations: the case of uk retail banks. Corporate Communications: An International Journal

Peacock L (2009) Lloyds tsb shareholders may revolt against pay policy. Personnel Today pp $21-22$

Pfeffer J (1998) Six dangerous myths about pay. Harvard business review 76(3):109-120

Shahzadi I, Javed A, Pirzada SS, Nasreen S, Khanam F (2014) Impact of employee motivation on employee performance. European Journal of Business and Management 6(23):159-166

Shaw JD, Gupta N (2015) Let the evidence speak again! financial incentives are more effective than we thought. Human Resource Management Journal 25(3):281-293

Silverman M (2004) Non-financial recognition. The Most Effective of Rewards Brighton: Institute for Employment Studies

Van der Stede WA (2009) Designing effective reward systems. Finance and Management (170):6-9

Storey J, Cressey P, Morris T, Wilkinson A (1997) Changing employment practices in uk banking: case studies. Personnel Review

Tausif M (2012) Influence of non financial rewards on job satisfaction: A case study of educational sector of pakistan. Asian Journal of Management Research 2(2)

Treanor J (2012) Lloyds bank reclaims bonuses. Guardian Newspaper

WI-bite G, Luk V, Druker J, Chiu R (1998) Paying their way: a comparison of managerial reward systems in the london and hong kong banking industries. Asia Pacific Journal of Human Resources 36(1):54-71 